\title{
Effects of Betaine on the Growth of the Fish Piauçu, Leporinus macrocephalus
}

\author{
Edivaldo Bento Normandes ${ }^{1}$, Rodrigo Egydio Barreto ${ }^{1}$, Robson Francisco Carvalho ${ }^{2}$ and \\ Helton Carlos Delicio ${ }^{1 *}$ \\ ${ }^{1}$ Departamento de Fisiologia; ${ }^{2}$ Departamento de Morfologia; Instituto de Biociências; UNESP; \\ deliciohc@yahoo.com.br; 18618-000; Botucatu - SP - Brasil
}

\begin{abstract}
In this study was tested the effect of betaine on the growth performance of the piauç fish. For this, twenty-one fish (mean $\pm S D$ : body weight: $14.9 \pm 1.3 \mathrm{~g}$ ) were randomly distributed in one out of three experimental treatments $(n=$ 7 each; 1 fish/aquarium): without betaine added in the food (control); $3.6 \mathrm{~g}$ betaine/Kg of food; $7.1 \mathrm{~g}$ betaine/Kg of food. The fish were exposed to experimental conditions for 60 days. Fish presented significant growth throughout experimentation, but no statistically significant difference was found for any parameter analyzed among the treatments, except for condition factor, which was higher in control group than betaine ones. Accordingly, it was concluded that betaine had no enhancing effect on growth of piauçu.
\end{abstract}

Abbreviations: SGR - specific growth rate; FCE - food conversion efficiency; FI - food intake; K - condition factor; TGC - thermal-unit growth coefficient

Key words: Growth, betaine, fish, feeding behavior

\section{INTRODUCTION}

Growth performance may be improved by using feeding stimulants in order to increase food intake (Papatryphon and Soares Jr., 2000a). Betaine, a common feed attractant, has been used as feed enhancer in fish, as reported for coho salmon Oncorhynchus kisutch (Castro et al., 1998), winter flounder Pleuronectes americanus (Melanie et al., 2000) and gibel carp Carassius auratus (Xue and Cui, 2001); it has also been mixed with other compounds for reaching this growth-stimulating effect, as reported for largemouth bass Micropterus salmoides (Kubitza et al., 1997), and striped bass Morone saxatilis (Papatryphon and Soares Jr., 2000a and b). In fact, several investigations have reported that betaine improved growth in fish (Clarke et al., 1994; Virtanen et al., 1994; Castro et al., 1998; Melanie et al., 2000; Beklevik and Polat, 2001). However, some authors have demonstrated that betaine had no affect on fish growth rate (Dabrowski and Kaushik, 1985; Duston, 1993; Garcia-Alcazar et al., 1994). These controversial results may be indicating a speciesspecific betaine effect, reinforcing the necessity to assess betaine effects on growth of other untested species, before applying it in commercial fish farms.

Piauçu, Leporinus macrocephalus (a South American Anostomid), is a species that has recently been commercially cultured for human consumption with a growing aquacultural activity

* Author for correspondence 
in South America (Albrecht et al., 2001). Accordingly, techniques to improve piauçu growth are very interesting goal for aquaculture practices in which growth rate represents an economically important trait (Moreau et al., 2003; Barreto et al., 2003). Betaine could be a possibility for improving piauçu growth rate. Hence, the present study examined the effect of betaine-incremented commercial fish food on growth of piauçu fish.

\section{MATERIALS AND METHODS}

Juveniles of piauçu, Leporinus macrocephalus, Anostomidae, Characiformes, were held for about two months in a 1200-L tank (1 fish/ 6 L), consisting the stock population. During this period, the water temperature averaged $24^{\circ} \mathrm{C}$, with continuous aeration through a biological filter; and the photoperiod was set up from 06:00 to $18: 00 \mathrm{~h}$ (12L: 12D). Fish were daily hand-fed in excess with tropical fish chow (Purina ${ }^{\circledR}$ Itda, Campinas, SP, Brazil, $36 \%$ protein diet).

From the stock population, 21 fish (mean \pm SD: standard length: $9.1 \pm 0.3 \mathrm{~cm}$; body weight: $14.9 \pm$ $1.3 \mathrm{~g})$ were randomly distributed in each experimental dietary treatment (each $\mathrm{n}=7 ; 1$ fish/aquarium - 541:) 1) without betaine added in the food (control group); 2) $3.6 \mathrm{~g}$ betaine/Kg of food; and 3) $7.1 \mathrm{~g}$ betaine $/ \mathrm{Kg}$ of food. These concentrations were based on Papatryphon and Soares Jr. (2000a). Each fish was exposed to its respective experimental treatment for 60 days. Fish weight and length were measured on day 0 (the threshold when fish were submitted to their respective dietary treatment), and on $30^{\text {th }}$ and $60^{\text {th }}$ days. Food ingestion was monitored everyday throughout this 60-day experimental period. Fish were tested isolated from each other for excluding social effects on growth, since based on pilot observations was reported heterogeneous growth (see Fernandes and Volpato, 1993; Volpato and Fernandes, 1994; Corrêa et al., 2003) and cannibalistic behavior in grouped piauçu (data not shown).

Each fish was hand-fed twice a day, at 09:00h and 15:00h throughout the experiment in an amount of food totaling $3 \%$ of fish biomass each day $\left(0-30^{\text {th }}\right.$ day, food weight $=450 \mathrm{mg} ; 30^{\text {th }}-60^{\text {th }}$ day, food weight $=600 \mathrm{mg}$ ). For preparing the betaineincremented food, commercial dry pellets for tropical fish (Purina ${ }^{\circledR}$ ltda, Campinas, SP, Brazil,
$36 \%$ protein diet) were ground, homogenized, and re-pelleted to allow incorporation of the betaine in the two proposed concentrations. This procedure was also performed for the food used in the control group (without betaine), for maintenance of similar handling procedures among groups.

At each feeding, a known amount of food was provided to each aquarium. Uneaten food was collected by siphoning 60 minutes later, dried to weight constancy and quantified. Thus, the daily food ingestion for each individual was calculated by the difference between the food dry weight before and after this handling. The rate of loss of uneaten food was evaluated by adding a weighed amount of food into the aquarium containing only water for 60 minutes and then collected, dried and re-weighted (Barreto et al., 2003). No loss of uneaten food due to leaching or breaking up was detected. Three times a week, fish excrements were siphoned and $20 \%$ of aquarium water level was replaced to avoid ammonia and nitrite accumulation.

During the experiment, water temperature averaged $24 \pm 0.2^{\circ} \mathrm{C} ; \mathrm{pH}$ ranged from 7.0 to 7.2 ; water-dissolved oxygen ranged from 6 to $7 \mathrm{mg} / \mathrm{L}$; and nitrite and ammonia were both lower than 0.05 $\mathrm{mg} / \mathrm{L}$. The photoperiod was set from 06:00 to 18:00 h (12L: 12D).

The parameters of growth performance were calculated based on $\mathrm{Fu}$ et al., (1998): specific growth rate $(\mathrm{SGR})=100\left(\operatorname{lnW}_{\mathrm{f}}-\ln _{\mathrm{i}}\right) \Delta \mathrm{t}^{-1}$, food conversion efficiency $(\mathrm{FCE})=100\left(\mathrm{~W}_{\mathrm{f}}-\mathrm{W}_{\mathrm{i}}\right) \mathrm{I}^{-1}$, food intake $(\mathrm{FI})=100 \mathrm{I} 2 \Delta \mathrm{t}^{-1}\left(\mathrm{~W}_{\mathrm{f}}+\mathrm{W}_{\mathrm{i}}\right)^{-1}$, and condition factor $(\mathrm{K})=100 \mathrm{~W} \mathrm{~L}^{-3}$. Based on Cho and Bureau (1998): thermal-unit growth coefficient $(\mathrm{TGC})$ was calculated as $=\left(\mathrm{W}_{\mathrm{f}}^{1 / 3}\right.$ $\left.\mathrm{W}_{\mathrm{i}}{ }^{1 / 3}\right) \mathrm{T}^{-1} \Delta \mathrm{t}^{-1}$ 100. Abbreviations are as follows: $\mathrm{W}$ is the fish weight $(\mathrm{g})$, being $\mathrm{Wf}$ the final and $\mathrm{Wi}$ the initial weight, $\mathrm{L}$ the standard length $(\mathrm{cm})$, I the total dry food consumed $(\mathrm{g}), \Delta \mathrm{t}$ (days) the time interval of each experimental period (see above), and $\mathrm{T}$ the temperature $\left({ }^{\circ} \mathrm{C}\right)$.

Kruskal-Wallis ANOVA was performed at each sampling time to test differences among the three groups (betaine groups, and control) and, when necessary, followed by Tukey HSD test of sum of ranks. Also, the differences within each group throughout the experimental periods were evaluated by Wilcoxon test (for two moments) or by Friedman's ANOVA test followed by Tukey HSD test of sum of ranks when necessary (for three or more moments). Statistical difference was 
accepted when $\mathrm{P}<0.05$. These statistical procedures were based on Zar (1999).

\section{RESULTS}

Body weight and condition factor mean values are expressed in Fig. 1. Body weight increased significantly for all groups throughout the 60-days period (Friedman ANOVA test; $\mathrm{P}_{\text {control }}=0.002$, $\left.\mathrm{P}_{\text {betaine }}-3.6 \mathrm{~g}=0.001, \mathrm{P}_{\text {betaine }}-7.1 \mathrm{~g}=0.03\right)$, but no difference was observed among groups (Kruskal Wallis ANOVA test; $\mathrm{P}_{\text {initial }}=0.12, \mathrm{P}_{30 \text { th }}=0.87$, $\left.\mathrm{P}_{60 \text { th }}=0.92\right) . \mathrm{K}$ increased significantly for all treatment throughout the 60-day period (Friedman ANOVA test; $\mathrm{P}_{\text {control }}=0.002, \mathrm{P}_{\text {betaine }-3.6 \mathrm{~g}}=0.041$, $\mathrm{P}_{\text {betaine - }} .1 \mathrm{~g}=0.006$ ), and the control group $\mathrm{K}$ was higher than those found for the betaine treatments in the last measurement $\left(60^{\text {th }}\right.$ day), with no significant difference between these betaine groups (Kruskal Wallis ANOVA test; $\mathrm{P}_{\text {initial }}=0.79$, $\left.\mathrm{P}_{30 \text { th }}=0.56, \mathrm{P}_{60 \text { th }}=0.046\right) . \mathrm{SGR}, \mathrm{FI}, \mathrm{TGC}$, and FCE mean values are expressed in Figure 2. No difference was observed in the SGR (Kruskal Wallis ANOVA test; $\mathrm{P}_{0-30}=0.61, \mathrm{P}_{30-60}=0.40$ ) and in the FI among treatments in each period (Kruskal Wallis ANOVA test; $\mathrm{P}_{0-30}=0.96, \mathrm{P}_{30-60}=$ $0.84)$, and for FI for each treatment between the different periods (Wilcoxon test; $\mathrm{P}_{\text {control }}=0.87$, $\left.\mathrm{P}_{\text {betaine }}-3.6 \mathrm{~g}=0.24, \mathrm{P}_{\text {betaine }}-7.1 \mathrm{~g}=0.86\right)$. FCE (Wilcoxon test; $\mathrm{P}_{\text {control }}=0.02, \mathrm{P}_{\text {betaine }}-3.6 \mathrm{~g}=0.02$ $\mathrm{P}_{\text {betaine - 7.1g }}=0.03$ ) and TGC (Wilcoxon test; $\mathrm{P}_{\text {control }}$ $=0.04, \mathrm{P}_{\text {betaine }}-3.6 \mathrm{~g}=0.04, \mathrm{P}_{\text {betaine }}-7.1 \mathrm{~g}=0.03$ ) increased significantly when comparing $30^{\text {th }}-60^{\text {th }}$ period with the $0-30^{\text {th }}$ period for all groups, but no difference was observed among groups in any period (Kruskal Wallis ANOVA test; FCE, $\mathrm{P}_{0-30}=$ $0.46, \mathrm{P}_{30-60}=1.0$ and TGC, $\mathrm{P}_{0-30}=0.68, \mathrm{P}_{30-60}=$ 0.60 ).
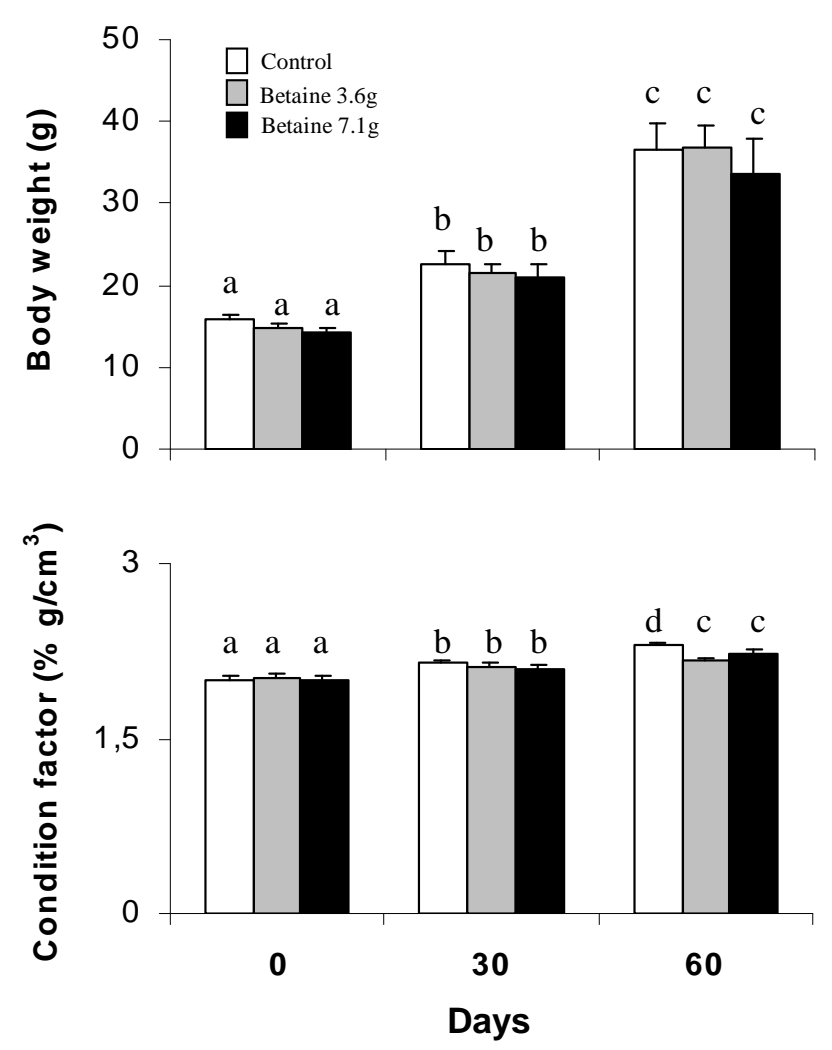

Figure 1 - Effects of betaine on piauçu growth performance. Body weight and condition factor (Mean $\pm \mathrm{SD} ; \mathrm{n}=7$ ). Different letters denote statistical differences among groups in the same period and within each condition throughout experimentation. 

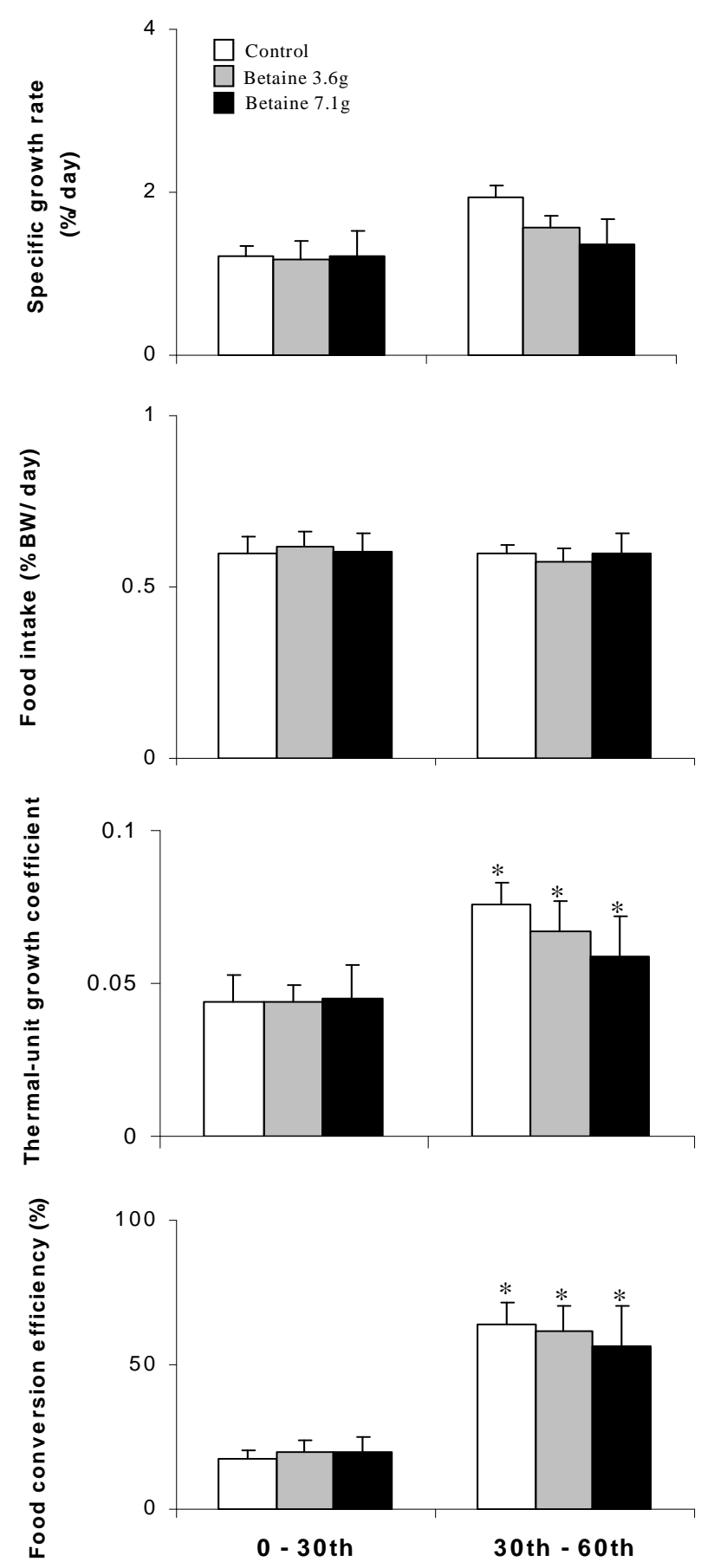

Figure 2 - Effects of betaine on piauçu growth performance. Specific growth rate, food intake, thermal-unit growth coefficient and food conversion efficiency (Mean $\pm \mathrm{SD} ; \mathrm{n}=7$ ). * denotes statistical differences between the periods.

\section{DISCUSSION}

The present study demonstrated that the addition of betaine on commercial dry-pelleted food did not improve growth performance of the piauçu fish.
Similarly, betaine did not improve growth in Coregonus schinzi (Dabrowski and Kaushik, 1985), Atlantic salmon, Salmon salar (Duston, 1993), sea bass, Dicentrarchus labrax, and sea 
bream, Sparus aurata (Garcia-Alcazar et al., 1994).

Body weight increased similarly throughout the experimental period for all groups with similar SGR and TGC among treatments in $0^{\text {th }}-30^{\text {th }}$ and $30^{\text {th }}-60^{\text {th }}$ period. The $\mathrm{K}$ increased significantly for all groups over time, but the control group had a higher $K$ in the final sampling $\left(60^{\text {th }}\right.$ day) when compared with betaine groups. These results indicated that betaine was not a growth enhancer for the piauçu. In contrast, several other studies reported that betaine increased the growth in fish, for instance see results obtained for coho salmon, Oncorhynchus kisutch (Castro et al., 1998); winter flounders, Pleuronectes americanus (Melanie et al., 2000); and rainbow trout, Oncorhynchus mykiss (Beklevik and Polat, 2001). Although betaine-supplemented foods have been sufficient for improving growth in fish (e.g. Beklevik and Polat, 2001), for some other species this effect was just observed in some transitory conditions, when increased palatability of food could be an important factor for increasing appetite. These transitory conditions are known to affect appetite due to new adaptation, such as transition from freshwater to seawater (e.g. Castro et al., 1998). Hence, according to these latter statements, future tests could not be excluded in this fish species through relevant transitory conditions, such as transition from endogenous (yolk), or live food to dry one, etc.

In the case of the $\mathrm{K}$, changes in this parameter reflected the nutritional or energy status of the fish (Lambert and Dutil, 1997; Grant and Brown, 1999), as K was altered either by storage or mobilization of energy reserves, such as muscle proteins (Barton et al., 2002). Thus, the lower $\mathrm{K}$ of betaine groups in comparison with control group $\mathrm{K}$ could have been indicating a catabolism state. Although the reported alterations in $\mathrm{K}$ might be a result of changes on the energy reserves and tissue biochemistry, the reported alterations might also be caused by changes in body water content (Lambert and Dutil, 1997), as betaine could have some osmotic effects in fish (Castro et al., 1998). However, data of this study did not allow to further speculate about these possibilities, so these questions concerning effects of betaine on $\mathrm{K}$ remain inconclusive and should be clarified in future studies.

Generally, betaine acts as feeding stimulant for fish, inducing an increase of FI, and consequently, improving growth rate (Papatryphon and Soares
Jr., 2000a). However, no increase of FI was found when comparing both betaine groups to the control group. Probably, betaine might be more effective in rather unpalatable foods. On the other hand, growth rate might increase due to an elevation of FCE, independently of an increase of food intake, as reported for coho salmon, Oncorhynchus kisutch, by Castro et al. (1998). Nevertheless, FCE increased equally for all groups in the $30^{\text {th }}-60^{\text {th }}$ period when compared to $0^{\text {th }}-30^{\text {th }}$ period. Thus, the lack of enhancing effect of betaine on the growth rate of piauçu was probably associated with the absence of enhancing effect on those possible growth mechanisms: FI and FCE.

\section{ACKNOWLEDGEMENT}

The authors thank Mr. A.C.B. Tardivo for very helpful technical assistance; Dr. S. Sarmento for English review; Dr. M. Dal Pai-Silva for some contributions for this research.

\section{RESUMO}

Testamos o efeito da betaína na performance de crescimento do peixe piauçu. Para tal, 21 espécimes (média \pm DP: peso corpóreo: $14,9 \pm 1,3$ $\mathrm{g})$ foram distribuídos aleatoriamente em um entre três tratamentos ( $\mathrm{n}=7$ cada; 1 peixe/aquário): ração sem acréscimo de betaína (controle), 3,6 g betaína/Kg de ração, 7,1 g betaína/Kg de ração. Os peixes foram submetidos às condições experimentais por 60 dias. Os peixes apresentaram crescimento estatisticamente significativo ao longo do experimento, porém nenhuma diferença estatística foi encontrada para qualquer parâmetro analisado, exceto para o fator de condição o qual foi maior no grupo controle do que nos grupos tratados com betaína. De acordo com isso, concluímos que a betaína não melhora $\mathrm{o}$ crescimento do piauçu.

\section{REFERENCES}

Albrecht, M. P.; Ferreira, M. F. N. and Caramaschi, E. P. (2001), Anatomical features and histology of the tract of two related neotropical omnivorous fishes (Characiformes; Anostomidae). Journal of Fish Biology, 58, 419-430. 
Barreto, R. E.; Moreira, P. S. A. and Carvalho, R. F. (2003), Sex-specific compensatory growth in fooddeprived Nile tilapia. Brazilian Journal of Medical and Biological Research, 36, 477-483.

Barton, B. A.; Morgan, J. D. and Vijayan, M. M. (2002), Physiological and condition-related indicators of environmental stress in fish. In: Adams, S. M. (Ed.). Biological Indicators of Stress in Fish. $2^{\text {nd }}$ ed. Bethesda: American Fisheries Society. pp. 111-148.

Beklevik, G. and Polat, A. (2001), Effects of DLalanine and betaine supplemented diets on the growth and body composition of fingerling rainbow trout (Oncorhynchus mykiss, W. 1972). Turkish Journal of Veterinary and Animal Sciences, 25, 301-307.

Castro. H.; Battaglia, J. and Virtanen, E. (1998), Effects of FinnStim on growth and sea water adaptation of Coho salmon. Aquaculture, 168, 423-429.

Cho, C. Y. and Bureau, D. P. (1998), Development of bioenergetic models and the Fish-PrFEQ software to estimate production, feeding ration and waste output in aquaculture. Aquatic Living Resources, 11, 199-210.

Clarke, W. C.; Virtanen, E.; Blackburn, J. and Higgs, D. A. (1994), Effects of a dietary betaine amino-acid additive on growth and seawater adaptation in yearling chinook salmon. Aquaculture, 121, 137-145.

Corrêa, S. A.; Fernandes, M. O.; Iseki, K. K. and Negrão, J. A. (2003), Effect of the establishment of dominance relationships on cortisol and other metabolic parameters in Nile tilapia (Oreochromis niloticus). Brazilian Journal of Medical and Biological Research, 36, 1725-1731.

Dabrowski, K. R. and Kaushik, S. J. (1985), Rearing of coregonid (Coregonus schinzi palea Cuv. Et Val.) larvae using dry and live food. 3. Growth of fish and developmental characteristics related to nutrition. Aquaculture, 48, 123-135.

Duston, J. (1993), Effects of dietary betaine and sodium chloride on seawater adaptation in Atlantic salmon parr (Salmo salar L.). Comparative Biochemistry and Physiology, 105A, 673-677.

Fernandes, M. O. and Volpato, G. L. (1993), Heterogeneous growth in the nile tilapia - social stress and carbohydrate-metabolism. Physiology and Behavior, 54, 319-323.

Fu, C.; Cui, Y.; Hung, S. S. O. and Zhu, Z. (1998), Growth and feed utilization by F-4 human growth hormone transgenic carp fed diets with different protein levels. Journal of Fish Biology, 53, 115-129.

Garcia-Alcazar, A.; Abellan, E.; Dehesa, M. R.; Arizcun, M.; Delgado, J. and Ortega, A. (1994), Pregrowout and growout for sea bream (Sparus aurata L.) and sea bass (Dicentrarchus labrax L.) with different fat/protein ratios. Boletino del Instituto Espanõl de Oceanografia, 10, 191-201.
Grant, S. M. and Brown, J. A. (1999), Variations in condition of coastal Newfoundland 0-group Atlantic cod (Gadus morhua): field and laboratory studies using simple condition indices. Marine Biology, 133, 611-620.

Kubitza, F., Lovshin, L. L. and Lovell, R. T. (1997), Identification of feed enhancers for juvenile largemouth bass Micropterus salmoides. Aquaculture, 148, 191-200.

Lambert, Y. and Dutil, J. D. (1997), Can simple condition indices be used to monitor and quantify seasonal changes in the energy reserves of Atlantic cod (Gadus morhua)? Canadian Journal of Fisheries and Aquatic Sciences, 54 : (Suppl. 1), 104-112.

Melanie, F., John, B. and John, C. (2000), Feeding stimulant for juvenile winter flounders. North American Journal of Aquaculture, 62, 157-160.

Moreau, Y.; Arredondo, J. L.; Perraud-Gaime, I. and Roussos, S. (2003), Dietary utilization of protein and energy from fresh and ensiled coffee pulp by the Nile tilapia, Oreochromis niloticus. Brazilian Archives of Biology and Technology, 46, 223-231.

Papatryphon, E. and Soares Jr., J. H. (2000a), The effect of dietary feeding stimulants on growth performance of striped bass, Morone saxatilis, fed-aplant feedstuff-based diet. Aquaculture, 185, 329-338.

Papatryphon, E. and Soares Jr., J. H. (2000b), Identification of feeding stimulants for striped bass, Morone saxatilis. Aquaculture, 185, 339-352.

Virtanen, E.; Hole, R.; Resink, J. W.; Slinning, K. E. and Junnila, M. (1994), Betaine/ amino acid additive enhances the seawater performance of rainbow trout (Oncorhynchus mykiss) fed standard fish-meal-based diets. Aquaculture, 124, 220.

Volpato, G. L. and Fernandes, M. O. (1994), Social control of growth in fish. Brazilian Journal of Medical and Biological Research, 27, 797-810.

Xue, M. and Cui, Y. (2001), Effect of several feeding stimulants on diet preference by juvenile gibel carp (Carassius auratus gibelio), fed diets with or without partial replacement of fish meal by meat and bone meal. Aquaculture, 198, 281-292.

Zar, J. H. (1999), Biostatistical analysis. $4^{\text {th }}$ ed. New Jersey: Prentice Hall.
Received: December 17, 2004 Revised: October 06, 2005; Accepted: April 04, 2006. 